\title{
Practical Research of the Angle of Thermodynamic Losses when Indicating Pressure in the Cylinder Diesel Engine
}

\author{
Željko Bulatovićn ${ }^{1)}$ \\ Dragan Knežević ${ }^{2}$ \\ Miodrag Milić ${ }^{1)}$
}

\begin{abstract}
Very important literary source for the study of work processes in the engine cylinders, for decades, has been an article by Günter Hohenberg "Definition und Eigenschaften des termodinamischen Verlust-winkels von Kolbenmaschinen", published in 1976 in the magazine Automobil Industrie, Edition 4. This article theoretically and practically (experimentally) deals with the topic of determining the angle of thermodynamic losses on the pressure curve without combustion measured in the engine cylinder. The special value of this research is in the experimental results obtained by averaging the measured data on a large number of different engines. It has been shown that these experimental results are useful for a quick, but quite accurate, determining of the angle of thermodynamic losses on the pressure curve without combustion, with any engine. Diagrams proposed by Hohenberg are used today, whether they are applied directly or used for comparison with the results of some of the more modern computational methods based on thermodynamic analysis of the processes in the engine cylinder. However, the theoretical approach by Hohenberg to the given problem through the equations he set, gives a pretty good idea of the most influential factors on the size of the angle of thermodynamic losses, but it has a lot of mistakes and rough approximations. This work is dedicated to the good and bad sides of this very important literature source through a comparison with one of the modern thermodynamic methods related to the issue of determining the angle of thermodynamic losses
\end{abstract}

Key words: IC engine, diesel engine, engine cylinder, compression ratio, pressure measurement, thermodynamic losses.

\section{Introduction}

$\mathrm{D}$ UE to the existence of heat losses and the loss of mass of working matter through clearances of piston-cylinder assembly, during the process of compression and expansion, the flow of pressure cycle without combustion is not symmetrical in relation to the top dead center (TDC). Maximum of the diagram has been moved and is placed before geometric TDC. The size of this angle, named the angle of thermodynamic losses (ATL), depends largely on the speed, and to some extent on the engine load and has the range of approximately one degree of angle of rotation of the crankshaft. There are calculations that show that the error in determining the ATL of one degree of the angle of rotation of the crankshaft can result in an error of approximately $10 \%$ of the calculated value of the indicator middle pressure [1]. Bearing in mind that the middle indicator pressure is one of the key parameters for a quantitative and qualitative evaluation of the work process, it is clear why in this case, and in similar calculations based on the indicated pressure in the engine cylinder, great attention must be paid to the more accurate identification of ATL, or position of TDC.

Identification of the location of TDC can be implemented using special sensors (magnetic, inductive, based on the piezo effect, etc.), which in fact follow the current position of the piston in the cylinder which is indicated. Use of these sensors is associated with the inevitable and not at all simple modification of the engine elements (cylinder head, piston, etc.) depending on where the sensors are placed. Since this work significantly relies to the article Günter Hohenberg published in 1976 in the magazine Automobil Industrie, Edition 4 [2], it is important to emphasize that Hohenberg, during his experimental studies to determine the position of TDC, applied the method of monitoring the distance between the piston and special electrodes inserted into the combustion chamber itself.

The application of special sensors to identify the position of TDC in the measured course of pressure in the engine cylinder seldom justifies the effort, owing to modifications on the elements of the engine and the complex process of measurements which must be synchronized with the measurement of the pressure flow. Mostly, the TDC assessment on the course of the measured pressure flow is performed by the analysis of indicated pressure without combustion, being understood that there must be synchronization between flows of measured pressure of the regular cycle (combustion) and cycles without combustion. In other words, the measurement in both cases must start at the same position of sensor triggers, which is used to manage the acquisition (usually encoder), compared with the same corner of crankshaft rotation during the work cycle engine cylinder that is indicated.

The paper first gives an overview of the significant and valuable reference which is even today, after four decades, considered a "compulsory" literature piece for the study of work processes in engines. It is about the article by Günter Hohenberg [2] published in 1976 in the magazine Automobil

\footnotetext{
${ }^{1}$ Military Technical Institute, Ratka Resanovića 1, 11132 Belgrad, SERBIA

${ }^{2}$ University of Belgrade, Faculty of Mechanical Engineering, Kraljice Katarine 16, 11020 Belgrade 35, SERBIA

Correspondence to: Željko Bulatović; e-mail:zetonbulat@gmail.com
} 
Industrie, Edition 4. The article is devoted to the problem of determining the top dead center (TDC), i.e. the angle of thermodynamic losses (ATL) to the measured pressure diagram when the cylinder combustion is missing in the engine.

The main and indisputable value of the Hohenberg's work is reflected in the experimental data which correctly predefined ATL. In doing so, a special sensor is used which registered the current position of the piston in the cylinder which is indicated. Experiments were carried out on several different engines followed by averaging the results.

Later, the more modern methods were examined, which is theoretically provided in reference [6], and is based on an explicit thermodynamic analysis of pressure flow and monitoring of the $T-s$ diagram forms with the process without combustion. This method is declared a method with a number of advantages: simply, it allows small deviations in the accuracy of determining the initial conditions of gas at the start of the compression process. In addition to determining the ATL, this method involves determining the actual value of the compression ratio.

Described studies were carried out for the needs of a complex task [9], on the specific diesel engine with twelve cylinders in V arrangement, with power of $882 \mathrm{~kW}$. Since it required high accuracy in determining the actual pressure flow in the function of the crankshaft rotation angle, and with special sensors for monitoring the status of one of the pistons not being used, the approach was using a subsequent search for the real position of TDC on measured pressure diagrams. Focusing on only one method was not reliable enough, thus a comparison with the results of an old method which contains experimentally obtained data was carried out [2], as well as a modern method [6], which promised good results. This paper is dedicated to the most important observations which have arisen from the mentioned, detailed research and its comparison with the obtained results.

\section{The theoretical approach to determining ATL shown in reference [2]}

As for the calculation set forth in reference [2], it can be very educational in order to observe the inevitability of understanding the angle of thermodynamic losses and most influential parameters on this phenomenon. However, in the original article [2], incorrectness is detected in some equations and quite rough approximations which other researchers, maybe even Günter Hohemberg, probably noticed after publishing of reference [2] and possibly worked on their correction.

Theoretical approach to determine the angle of thermodynamic losses will be briefly presented in [2], with the emphases on the areas for which the authors of this paper believe to be disputable. They began with the fact that the ATL $(\Delta \alpha)$ is the result of a collective functioning of angle losses due to the heat exchange with the environment $\left(\Delta \alpha_{W}\right)$ and the angle of losses due to the passage of matter through working gaps in the combustion chamber, primarily in the piston-cylinder assembly $\left(\Delta \alpha_{L}\right)[2]$ :

$$
\Delta \alpha=\Delta \alpha_{W}+\Delta \alpha_{L}
$$

Then, he developed a special methodology for assessment of the first and the second component.

According to the disclosed method, determining $\Delta \alpha$ is based on the recorded pressure in an engine cylinder when it failed combustion, whereby it analyzes only a small diagram domain of one degree crankshaft, just before the TDC, which is assumed to be of value $\Delta \alpha$. With the calculation moving so as to adopt the assumption that $\Delta \alpha=0$ (maximum pressure in TDC), a theoretical basis for the calculation is the first law of thermodynamics, which is in differential form as follows:

$$
\begin{gathered}
d q=p d v+d u \\
d u=c_{v} \cdot d T
\end{gathered}
$$

It has been adopted that the air in the cylinder during the high-pressure part of the $p-\alpha$ diagram behaves as an ideal gas, so the equation applies:

$$
p \cdot v=R \cdot T
$$

With its differentiation we get:

$$
p \cdot d v+d p \cdot v=R \cdot d T
$$

As the specific heats $c_{p}, c_{v}$ and gas constant $R$ satisfy the relation:

$$
c_{p}=c_{v}+R
$$

it follows that [2]:

$$
d q=p_{\max } \frac{c_{p}}{R} d v
$$

Specific volume and derivative of the specific volume per angle of the crankshaft, respectively are obtained from the equations:

$$
\begin{array}{r}
v=\frac{1}{m}\left[\frac{V_{h}}{\varepsilon-1}+\frac{V_{h}}{2} \cdot\left[1+\frac{1}{\lambda}-\cos (\alpha)-\frac{1}{\lambda} \cdot \sqrt{1-(\lambda \sin (\alpha))^{2}}\right]\right] \\
\frac{d v}{d \alpha}=\frac{1}{m} \cdot\left[\frac{V_{h}}{2}\left[\sin (\alpha)+\frac{\lambda \sin \alpha \cos \alpha}{\sqrt{1-(\lambda \sin (\alpha))^{2}}}\right] \cdot \frac{\pi}{180}\right]
\end{array}
$$

In the equations (8) and (9), $\lambda$ refers to kinematic characteristics of the piston mechanism. Adopting that the distance between the maximum pressure of TDC due to heat exchange between the air and the surrounding areas $\Delta \alpha_{W} \approx 1$ angle of rotation of the crankshaft, expressed in degrees of the rotation angle of the crankshaft $\left({ }^{\circ} \mathrm{CS}\right)$, after a series of transformations and simplifications proposed in [2], the following is the final expression for calculating the components of ATL due to heat exchange between air intake and the environment:

$$
\Delta \alpha_{W}=\frac{m \Delta q}{p_{\max } \frac{c_{p}}{R} K_{1}}=\frac{\Delta Q}{p_{\max } \frac{c_{p}}{R} K_{1}}
$$

It has been added [2] that $\Delta \alpha_{W}$ is expressed in ${ }^{\circ} \mathrm{CS}$, while $\Delta Q$ (i.e. $m \cdot \Delta q$ ) is expressed in $\frac{\mathrm{kcal}}{{ }^{\circ} \mathrm{CS}}$, and pressure $p_{\max }$ is not a listed unit. It is difficult to understand the expression of heat exchange $\Delta Q$ in $\frac{\mathrm{kcal}}{{ }^{\circ} \mathrm{CS}}$ instead of in $\frac{\mathrm{kJ}}{{ }^{\circ} \mathrm{CS}}$, except in the case of accidental or typing error.

$$
K_{1}\left(\frac{\mathrm{m}^{3}}{{ }^{\circ} \mathrm{CS}^{2}}\right) \text { constant, as the geometric characteristic of the }
$$
piston mechanism, is calculated through the equations $(8,9)$ at 
an angle which differs $1{ }^{\circ} \mathrm{CS}$ from the geometric TDC, but this is due to the parity of the function $V(\alpha)$, eq. (8), instead of left shifted to the right $\left(\alpha=361^{\circ} \mathrm{CS}\right)$. This resulted in a required positive value of the constant $K_{1}$. For calculating constant $K_{1}$, a final equation is proposed [2]:

$$
K_{1} \approx 3,05 \cdot 10^{-4} \cdot V_{h} \cdot\left(\frac{1}{2}+\lambda\right)
$$

where $V_{h}\left[\mathrm{~m}^{3}\right]$ cylinder engine volume, and $\lambda$ kinematic characteristics of the piston mechanism.

Eq. (9) is here correctly written, as opposed to references [2], where instead of the article $\frac{\lambda \cdot \sin \alpha \cdot \cos \alpha}{\sqrt{1-(\lambda \sin (\alpha))^{2}}}$ its term is equivalent to $\frac{\lambda \cdot 2 \cdot \sin \alpha \cdot \cos \alpha}{\sqrt{1-(\lambda \sin (\alpha))^{2}}}$. By the correction of these errors the correct approximate equation which is compared to eq. (11) is obtained and states:

$$
K_{1} \approx 3,046 \cdot 10^{-4} \cdot V_{h} \cdot\left(\frac{1}{2}+\frac{\lambda}{2}\right)
$$

It should also be noted that the right side of eq. (9) is multiplied by $\pi / 180$, which means that the estimate is done in angular domain expressed in radians. Therefore the constant $K_{1}$ does not dimensionally correspond to $\frac{\mathrm{m}^{3}}{{ }^{\circ} \mathrm{CS}^{2}}$ as indicated in the [2].

By analyzing the term given by eq. (10), we can conclude that the angle of "thermal" losses depends directly on the exchanged heat $\Delta Q$ on a narrow segment of the angle of rotation of the crankshaft $\left[306^{\circ}-\Delta \alpha, 360^{\circ}\right]$ expressed in degrees, geometric characteristics of reciprocating mechanism contained in the coefficient $K_{1}$ and inversely proportional to the maximum pressure cycle without combustion in a given mode of operation.

To assess the deviation angle of the maximum temperature in relation to the TDC $\left(\overline{\Delta \alpha_{W}}\right)$ with no combustion cycle, when the temperature increase $d T$ (i.e. internal energy $d u$ ) equals zero, eq. (2) becomes:

$$
d q=p d v
$$

Assuming that in this case, the pressure has a value close to $p_{\max }$, using equations $(10,13)$, the following equation is proposed [2]:

$$
\overline{\Delta \alpha_{W}}=\frac{m \Delta q}{p_{\max } K_{1}}=\frac{\Delta Q}{p_{\max } K_{1}} \approx 3,5 \cdot \Delta \alpha_{W}
$$

So, for the averaged $c_{p}$ as a function of medium temperature of the gas in the cylinder, $\overline{\Delta \alpha_{W}}$ is approximately quotient of greater than $\Delta \alpha_{W}$. In the eq. (14) the quotient $\frac{c_{p}}{R}$ is estimated to be $\approx 3.5$, although using the eq. (6), empirical equations for the specific air heat as an ideal gas at constant volume [3]:

$$
\begin{aligned}
c_{v}= & 144,5\left[-0,2925\left(T-T_{U Z}\right) 10^{-6}+\right. \\
& \left.+15,536\left(T-T_{U Z}\right) 10^{-4}+4,896\right]\left(\frac{\mathrm{J}}{\mathrm{kgK}}\right)
\end{aligned}
$$

and empirical equations for the specific heat of air as an ideal gas at constant pressure [4]:

$$
\begin{aligned}
c_{p}= & 1403,06-360,72 \cdot \frac{1000}{T}+108,24 \cdot\left(\frac{1000}{T}\right)- \\
& -10,79 \cdot\left(\frac{1000}{T}\right)^{3}\left(\frac{\mathrm{J}}{\mathrm{kgK}}\right)
\end{aligned}
$$

for turbocharged, four-stroke, diesel-engine $V$ construction with 12 cylinders, obtained that the average quotient value is closer to 3.8. However, it has been shown that the coefficient of 3.5 actually more closely corresponds to the maximum temperature calculated based on the eq. (4), where it is adopted that the air behaves as an ideal gas, as the authors of this study tested the dependence of the mentioned diesel engine.

Designation $T_{U Z}$ in equation(15) refers to the temperature at the time of closing the intake valve, expressed in Kelvin.

The area above the piston in the internal combustion engine from the rest of the cylinder is sealed by piston rings. However, they cannot provide a complete seal, and there is a loss of work matter through micro-cracks. The loss of gas from the cylinder capacity $d m$ is a function of time and effective flow cross-section area $\left(A_{L}\right)$. In these areas, supercritical pressure ratio is present. By applying known equations of the flow [1-3], after the introduction of an imaginary small cylinder with a piston appended to the combustion chamber, a final approximate expression for calculating the angle components of thermodynamic losses due to the passage of work matter through the gaps $\Delta \alpha_{L}$ [2] is proposed:

$$
\Delta \alpha_{L} \approx \frac{1,927 \cdot T \cdot A_{L}}{n \cdot K_{1}}
$$

Eq. (17) gives a good internalized picture of the most important factors, and the way they affect the $\Delta \alpha_{L}$, and they are: $T(\mathrm{~K})$ temperature of the air at a maximum pressure $p_{\max }, n$ $(\mathrm{rpm})$ engine speed, $A_{L}\left(\mathrm{~m}^{2}\right)$ the effective cross-sectional area, and questionable constant $K_{1} \frac{\mathrm{m}^{3}}{{ }^{\circ} \mathrm{CS}^{2}}$ calculated according to eq. (11).

Experiments have shown that the effective cross-sectional area, through which gas is discharged from the cylinder, rapidly approaches a constant value with increasing gas pressure in the cylinder (Fig.1). To calculate the approximate value of the effective cross-section $A_{L}$ in $\left(\mathrm{m}^{2}\right)$ empirical equation supported by the results of measurements is suggested [2]:

$$
A_{L}=(0,003 \div 0,004) \cdot D
$$

The dependence is given by equation (18) and Fig. 1 is experimentally determined in reference [3].

Finally, it must be repeated that quite a rough approximation in this robust calculation procedure decisively influences that they cannot get anywhere near the expected results. The authors of this paper made such a statement based on the experiments performed over the already mentioned turbocharged diesel engine $V$ constructed with 12 cylinders. Similar experiences are recorded also in the tests described in $[3,5,9]$, where Hohenberg's theoretical approach to this problem used in order to clarify the phenomenon of ATL, but is not shown and the estimate gave very poor results. 


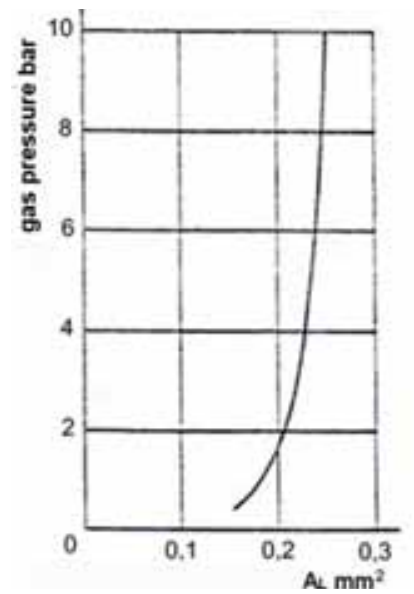

Figure 1. The dependence of the effective cross section on the gas pressure in the cylinder [2]

\section{Experimental results of the determination of ATL presented in reference [2]}

What is extremely valuable in the article [2], are the results obtained by the measurement. The results of the particular position of TDC obtained with the sensor placed in the combustion chamber, averaging data for a number of different engines, over a wide range of the number of revolutions from $600 \mathrm{rpm}$ to $5000 \mathrm{rpm}$.

It has been noted that, at a constant speed, the total ATL increases for a certain, not too great value, as it reduces the load on the engine, or the mean effective pressure. Averaged growth curve $\Delta \alpha$ (from 0.9 to 1.1 ) at a decreasing load curve for the rated speed of $1500 \mathrm{rpm}$ is shown in Fig.3. Previously exhibited estimate provides an answer to this question. With a constant factor $K_{1}$ increasing pressure $p_{\max }$ with increasing amounts of charge (mass of gas in the cylinder) significantly affects the decrease of $\Delta \alpha_{W}$ than it is growing due to the increase in mass of the gas in the cylinder $(m)$, while the gas temperature $\mathrm{T}$ at the maximum pressure remains about the same $\left(\Delta \alpha_{L}\right.$ does not change). Correction of $\Delta \alpha$ at 0.1 to 0.2 degrees angle of rotation of the crankshaft depending on the load level, according to the diagram in Fig.3, is necessary to take into account when assessing the ATL to the diagram given in Fig.2.

Although the diagram in Fig.2 represents a solid recommendation for a quick, approximate determination of ATL for any engine, it is noted that in the range of lower speeds recommended $\Delta \alpha_{W}$ is in a good agreement with Fig. 2, while in the areas of higher speeds, in some engines, measured values show a tendency towards smaller or larger deviations [2].

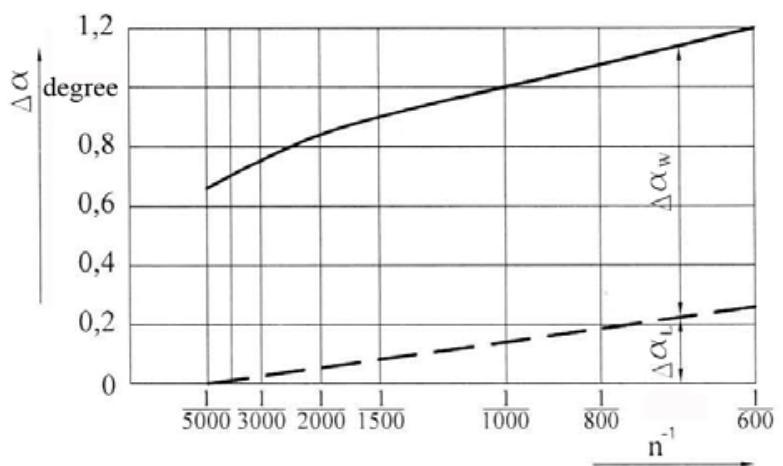

Figure 2. Medium ATL value for more engines depending on rpm at the full load [2]

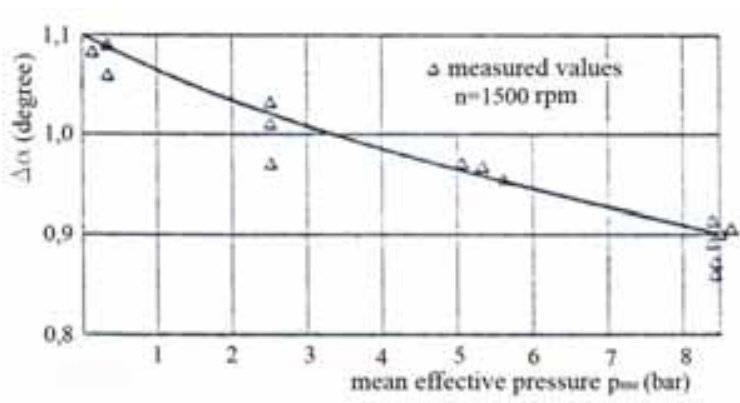

Figure 3. Correction of ATL by taking into account the load at $1500 \mathrm{rpm}$ [2]

\section{Method for determining the ATL based symmetry of T-s diagram in the environment of TDC}

From the new evaluation methods of ATL we should single out those that are based on a mathematical modelling of $\mathrm{p}-\alpha$ diagram, the correction of $p$ - $\alpha$ diagram monitoring symmetry/asymmetry pressure flow $p$ - $V$ diagram, monitoring the position of inflection points $p$ - $\alpha$ diagrams, explicit thermodynamic analysis of flow and pressure monitoring forms $T-s$ diagram. The latter two approaches deserve particular attention. Explicit thermodynamic analysis of the pressure flow is quite an efficient procedure which is sensitive to errors in assessing initial conditions, while for the tracking form $T-s$ diagram could be said that it is a lot less complex and efficient method of evaluating the ATL. In that sense, it is a very interesting method theoretically described in [6]. The efficacy of this method on a line four-cylinder engine with spark ignition of the mixture is shown in reference [7]. In the already mentioned case, turbocharged diesel engines in construction with 12 cylinders, it has been shown that, with the adequate preparation in advance, the method is applicable even on higher compression ratio engines, i.e. on diesel engines [9]. This in advance preparation is presented in Fig.4, and it implied:

1. "Filtering" the measured pressure curve without combustion in the cylinder (blue dots in Fig.4) by application of the Fourier interpolation, trigonometric polynomial for table functions, in order to obtain a new curve (red line in Fig.4), which eliminates systematic measurement errors contained in the noise and illogical parts of the diagram as convexity in the vicinity of the maximum (between 358 and 360 degrees of crankshaft rotation angle).

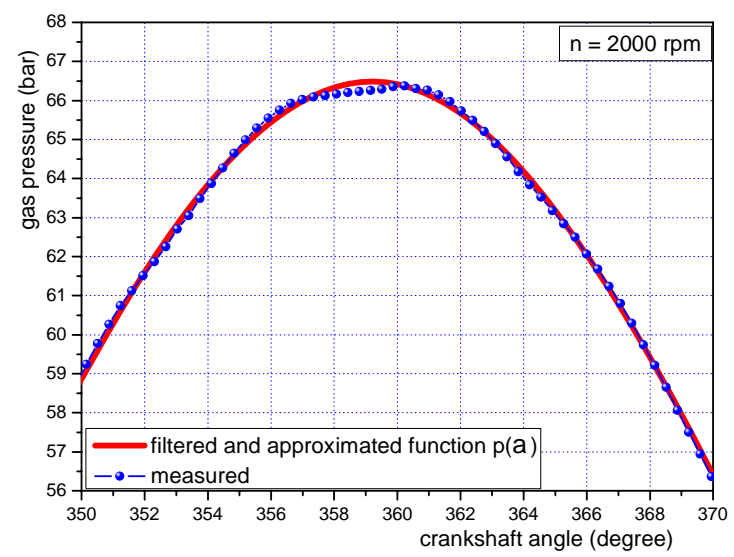

Figure 4. Measured and filtered (approximated) curve of pressure without combustion 
2. The new resulting pressure curve $p(\alpha)$, as well as the table functions, the greater the number of dots, i.e. smaller the distance between adjacent values of the angle of rotation of the crankshaft (red line in Fig.4), which significantly reduces the error in the numerical solution of the corresponding differential equation and replaces finite differences. In Fig.4, the distance between the adjacent blue dots amounted to 0.36 degrees angle of rotation of the crankshaft and in filtered pressure curve $p(\alpha)$ (red curve) is only 0.1 degrees.

As the flow of pressure in the four-stroke engine cylinders is a periodic function with the period of $4 \pi$, the Fourier interpolation trigonometric polynomial is used for obtaining filtered pressure curve. After this, the original method described in reference is applied [6], with excellent results in agreement with the experimental results by Hohenberg, also there have been no shortcomings in the Hohenberg's theoretical approaches.

The theoretical basis of the method described in [6] is based on the analysis of equations for entropy change in compression and expansion in the immediate vicinity of the maximum $T-S$ diagrams, and the conclusion that there must be a symmetry of $T$ $s$ diagram of the process without combustion, in the immediate vicinity of the given maximum, if compression degree $(\varepsilon)$ and $\operatorname{ATL}(\Delta \alpha)$ are correctly determined.

If it is adopted that the process without combustion takes place without the loss of mass, the transformation of energy per mass unit can be represented by the first law of thermodynamics, thus equations $(2,3)$ are given. It has been adopted that the air in the cylinder during the high-pressure part of $p$ - $\alpha$ diagram behaves as an ideal gas, thus the eq. (4) is applied, from which the following equation is given:

$$
\frac{d v}{v}+\frac{d p}{p}=\frac{d T}{T}
$$

For specific volume and derivative of the volume of the angle of rotation of the crankshaft the equations $(8,9)$ are valid.
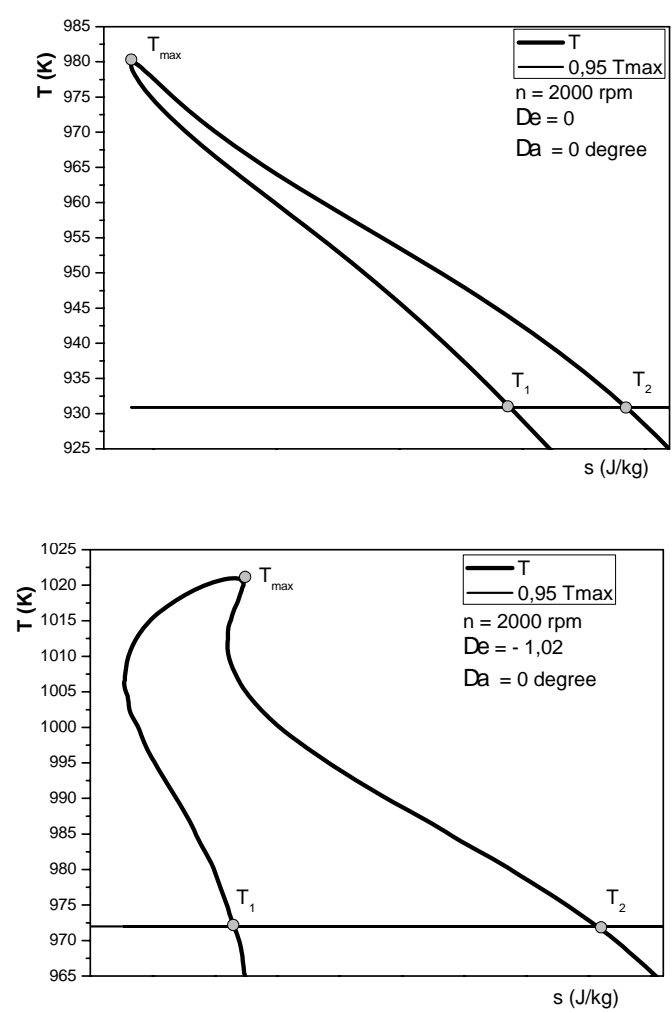

According to the second law of thermodynamics the change in specific entropy is:

$$
d s=\frac{d q}{T}
$$

By applying the equations $(1,2,19,20)$ the specific entropy change can be expressed as:

$$
d s=c_{v} \cdot \frac{d T}{T}+R \cdot \frac{d v}{v}
$$

As the studied interval around TDC temperature changes are relatively small, and the process takes place at a very small change in volume, specific heat $c_{v}$ for air can be determined from the expression (15). Specific heats $c_{p}, c_{v}$ and gas constant $R$ of air as an ideal gas satisfies the eq. (6).

The mass of the gas in the cylinder is calculated according to the equation of the state of the gas at the time of closure of the intake valve:

$$
m=\frac{p_{c i l U Z} \cdot V_{U Z}}{R \cdot T_{U Z}}
$$

The temperature $T_{U Z}$ is roughly estimated using the empirical expression given in [8]:

$$
T_{U Z}=T_{u k} \cdot 0,833+86
$$

In the previous two equations index $u k$ stands for the intake manifold, while the index $U Z$ stands for the closing angle of the intake valve. Because of the assumption that the working substance behaves as an ideal gas, mean temperature of the gas during the indication of the engine, can be determined from eq. (4).

Symmetry of the $T-s$ diagram in the immediate vicinity of the maximum temperature values by this procedure can be achieved only if compression ratio $(\varepsilon)$ and $A T L(\Delta \alpha)$ are correctly specified at the same time.

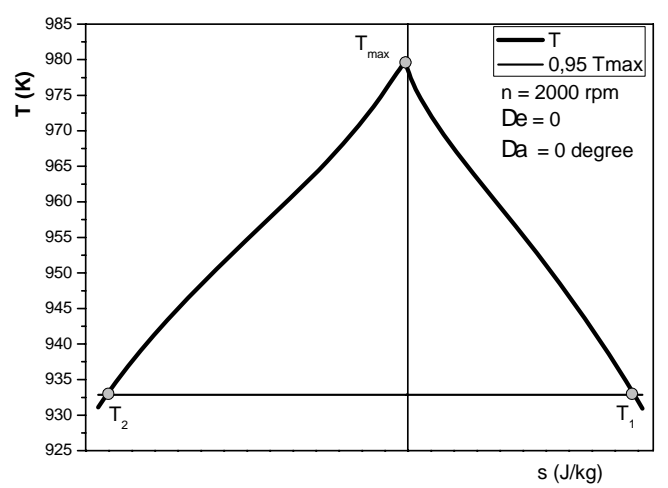

a)

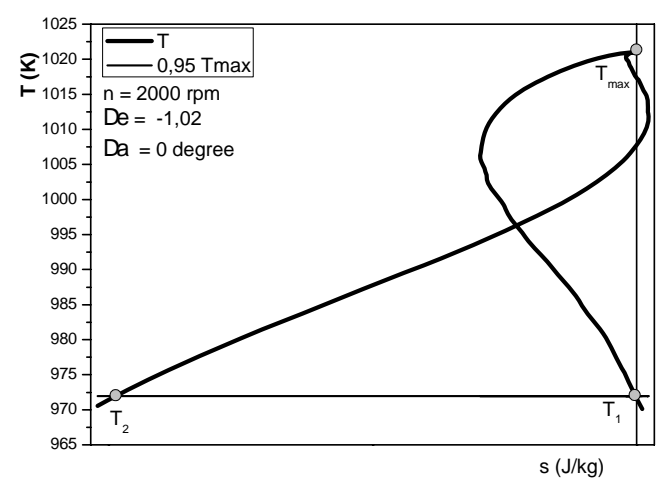



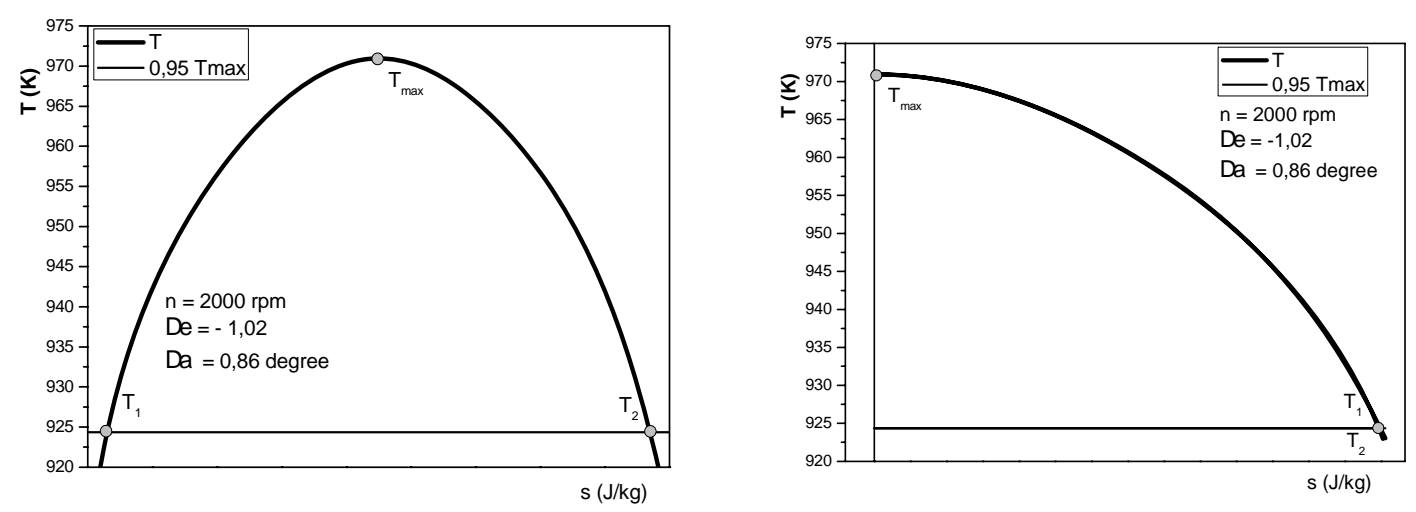

c)

Figure 5. Stages in the process of searching for the parameter values $\Delta \alpha$ and $\Delta \varepsilon$

After the replacement of the differential with corresponding finite differences, the equation for calculating the specific growth rate of entropy (21) takes on the form:

$$
\Delta s_{i}=c_{v}\left(T\left(\alpha_{i}\right)\right) \cdot \frac{\Delta T\left(\alpha_{i}\right)}{T\left(\alpha_{i}\right)}+R \cdot \frac{\Delta v\left(\alpha_{i}\right)}{v\left(\alpha_{i}\right)}
$$

A principled course of the specific entropy can now be obtained from the equation:

$$
s_{i+1}=s_{i}+\Delta s_{i}
$$

The process of evaluating the angle of thermodynamic losses and compression level is based on the variation of these parameters until the symmetry $T-s$ diagram is made in the environment of its maximum, ie. on the way from a value temperature $T_{1}$ to maximum ( $T_{\max }$ ), and from $T_{\max }$ to $T_{2}$, as depicted in Fig.5. It is clear that temperatures $T_{1}$ and $T_{2}$ have the same value, but are located on the opposite sides in respect to $T_{\max }$.

An illustration of the process of searching for the appropriate values $\Delta \alpha$ and $\Delta \varepsilon$ is shown in Fig.5. In this figure, $\Delta \varepsilon$ represents a correction of the compression ratio in relation to its presumed-theoretical value. The diagrams on the left show that the specific entropy is directly calculated from equation (25). Better insight into the symmetry of the $T-S$ diagram can be achieved if you start from point $k$ where the recorded temperature is $T_{\max }$, then move to the point where $T=T_{1}$ whereby the specific entropy is calculated according to the equation:

$$
T_{\max } \rightarrow T_{1} \Rightarrow s_{k-i-1}=s_{k-i}-\Delta s_{k-i}
$$

on the other side, from the point $T_{\max }$ to the point $T_{2}$ according to the equation:

$$
T_{\max } \rightarrow T_{2} \Rightarrow s_{k+i+1}=s_{k+i}-\Delta s_{k+i}
$$

In this case, T-s is obtained on the segment $T_{\max } \rightarrow T_{2}$ as a mirror image and facilitates the visual monitoring of symmetry of the T-s curve compared to $T_{\max }$, in an iterative process of searching for the unknown parameter $\Delta \alpha$ and $\Delta \varepsilon$. Such diagrams are shown on the right side of Fig.5.

Compression ratio higher than the real value leads to the curve $T-s$ bending to the left, while the compression ratio lesser than the real value results in the curve $T-s$ bending to the right [6].

The main sources of compression deviations should be sought out in the insufficiently exact estimate rather complex geometrical compression volume and the change in volume due to deposits sedimented on the walls of the combustion engine chamber during operation or in the wide foundry tolerances during the preparation of the cylinder head. Since the compression affects the flow curve of specific volume, and therefore the incrementing specific entropy, it must inevitably have an impact on the shape of the $T$-s diagram.

The existence of errors in determining the position of TDC on the T-s diagram, is manifested with a loop that has no thermodynamic sense (Fig. 5 b right). By varying the position of TDC the shape of the loop can be affected and a sign of going in the right direction is the disappearance of the loop and the crossing of the $T$-s diagram into a concave curve with a maximum. With precisely defined parameters $\Delta \alpha$ and $\Delta \varepsilon$, a symmetrical $T-s$ diagram is obtained in the immediate vicinity $T_{\max }$ (Fig.5c).

Fig. 6 gives a better notion of the influence of compression ratio on the symmetry of the $T$-s diagram, where the angle of thermodynamic losses $\Delta \alpha$ is not changed, and has a previously defined value of 0.86 . In this figure, black curve refers to the identified value of the correction of the compression ratio, when a symmetrical $T-s$ diagram $(\Delta \varepsilon=-1.02)$ is obtained. Below it are blue curves, obtained by increasing the identified values for $\Delta \varepsilon$ by 0.1 . They show an evident tendency of bending to the left as $\Delta \varepsilon$ grows in relation to the identified values. Above the black curve is a series of red curves, which are obtained by reducing the identified value for $\Delta \varepsilon$ by 0.1 . In this case, the observed is the increased bending to the right, as $\Delta \varepsilon$ decreases.

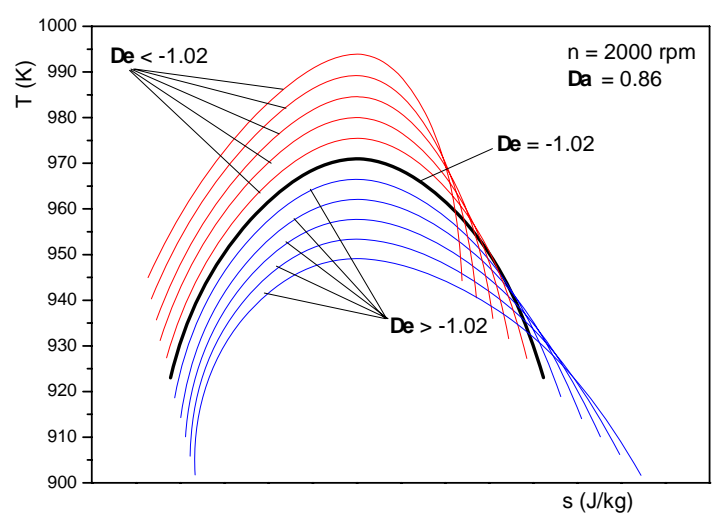

Figure 6. The impact of the compression ratio on the symmetry of $T-S$ diagram

It turned out that such application of $T-S$ diagram's symmetry criteria, with the aforementioned diesel engines, is possible to determine the parameter $\Delta \alpha$ which agrees well with the values recommended in [2], which are obtained on the basis of diagrams given in Figures 2 and 3. Determination of the parameters $\Delta \alpha$ and $\Delta \varepsilon$ was based on a series of cycles without combustion measured at different speeds (1500 rpm to $2000 \mathrm{rpm}$ ), with loads which equalled about $75 \%$ of 
maximum load, using the iterative process, which has the ultimate goal of obtaining a symmetrical $T-S$ diagram in the vicinity of the maximum temperature of the gas at the indicated cylinder (Fig.5c). As during indication cylinder engine sucked clean air in for the estimate, thermodynamic properties of air were used, where it is viewed as an ideal gas. This approximation does not lead to major errors during the calculation. More detailed analyses indicate that the imple-

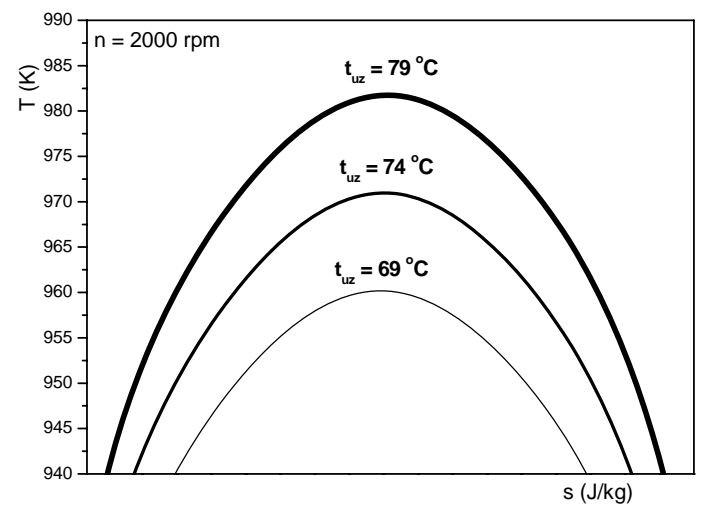

Figure 7. Dependence of $T-s$ diagram on the set of the initial conditions mentation of the ideal gas state instead of the real gas state equations can result in estimate errors in more important engine parameters of a maximum of $1.5 \%$ [3].

The averment presented in [6], that the accuracy of the estimate by this method does not decrease if the temperature of the gas at the moment of closing the intake valve $T_{U Z}$ as an initial condition which is required to be specified, does not get assessed precisely, is proved to be true.

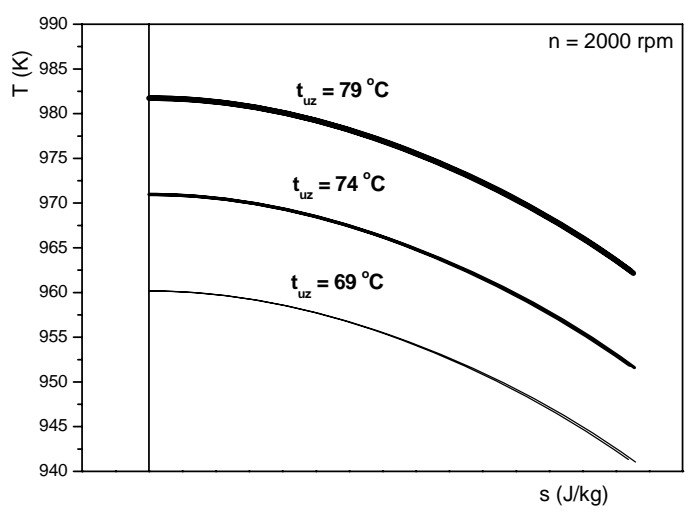

ngement, with power of $882 \mathrm{~kW}$, with the required high accuracy in determining the actual pressure flow as a function of the crankshaft rotation angle.

The paper at first presents the method by Günter Hohenberg in an article published in 1976 in the journal Automobil Industrie, $4^{\text {th }}$ edition.

In the theoretical approach to ATL determining, Hohenberg relies on the thermodynamic analysis in a narrow angular domain of one degree of the crankshaft rotation angle, shortly before the TDC. This analysis gives a pretty good idea about the inevitability of the ATL appearance and the most influential parameters on this phenomenon. However, the presented equations include pretty rough simplifications, even inaccuracies, for which this theoretical approach is practically unusable.

The next item is dedicated to the Hohenberg's experimental data with accurately determined ATL, where a special sensor was used, which registered the current position of the piston in the cylinder that is being indicated. Experiments were carried out on several different engines, followed by averaging of the results.

He then discussed the process of more accurate calculation estimates of compression degree and ATL, based on achieving symmetry of the T-s diagram in the immediate surroundings of TDC. It has been shown that with the adequate prior preparation, which raises the estimate accuracy, said method can be used with specified diesel engines. The prior preparations entailed filtering of the pressure curve, using the Fourier trigonometric interpolation polynomial, that were also obtained, are the new table functions with smaller spacing between adjacent values of the crankshaft rotation angle. A procedure is displayed which allows for better visual monitoring of $T-s$ diagram's symmetry during the search for actual values for the compression ratio and ATL, which is based on the display of T-s diagram as a "mirror image" in relation to a vertical containing the calculated maximum temperature. By the use of this method the following has been observed:

1. The excellent agreement with experimental results by Hohenberg has been achieved. ATL value of 0.86 degrees has been identified and completely corresponds to the diagrams offered by Hohemberg, where the correction value of the compression ratio is -1.02 .
This paper presents practical experiences and methods used in determining of the ATL processes without combustion on a specific diesel engine with twelve cylinders in a $V$ arra- 
2. Since there were no deficiencies as in Hohenberg's theoretical approaches, it can be expected that combining this approach with the experimental results by Hohenberg achieves a solid base for quite an accurate assessment of ATL even with other engines.

3. It has been shown that the method does not require high accuracy with which the initial conditions of the estimate are approximated and are not overly complicated.

\section{Appendix - Notations}

$A_{L}$

$c_{p}, c_{v} \quad$ specific heat

$D \quad$ piston diameter

$K_{l} \quad$ Hohemberg constant

$m \quad$ mass

$n \quad$ crankshaft speed

$p \quad$ pressure

$R \quad$ gas constant

$S \quad$ entropy

$T$ temperature

TDC top dead center

$u \quad$ internal energy

$u k \quad$ intake manifold

UZ closing angle of the intake valve

$v \quad$ specific volume

$V_{h} \quad$ piston displacement

$q \quad$ released heat

$\alpha \quad$ angle of rotation crankshaft

$\varepsilon \quad$ compression ratio

$\Delta \alpha \quad$ angle of thermodynamic losses

$\Delta \alpha_{L} \quad$ angle of thermodynamic losses due to the passage of matter through working gaps

$\Delta \alpha_{W} \quad$ angle of thermodynamic losses due to heat exchange with the environment

$\overline{\Delta \alpha_{W}}$ angle of the maximum temperature in relation to the TDC
$\Delta \varepsilon$

${ }^{\circ} \mathrm{CS}$

correction of the compression ratio

kinematic characteristics of the piston mechanism degree rotation of crankshaft

\section{References}

[1] JANKOV,R.: Mathematical modeling of current-dynamic processes and operating characteristics of diesel engines, quasi-stationary models, Part I, basics, Scientific Book, Belgrade in 1984.

[2] HOHENBERG,G.: Definition und Eigenschaften des termodinamischen Verlust-winkels von Kolbenmaschinen, Automobil industrie 4/76, pp.15-21, DK 621.43/512:621.1.016.7, 1976.

[3] CVETIĆ,M.: The research of real gas-thermodynamic parameters harnesses diesel engine-turbocharger master's thesis, Faculty of Mechanical Engineering, University of Belgrade, Belgrade, July 1990.

[4] PIPITONE,E., BECCARI,A.: Determination of TDC in internal combustion engines by a newly developed thermodynamic approach, Applied Thermal Engineering, Oct. 2010, Vol.30, No.14-15, pp.19141926 ,

[5] TOMIĆ,M.: Parameter identification of mathematical models of current and thermodynamic processes of diesel engines, Doctoral dissertation, Faculty of Mechanical Engineering, University of Belgrade, Belgrade in 1987.

[6] TAZEROUT,M., LE CORRE,O., ROUSSEAU,S.: TDC determination in IC engines based on the thermodynamic analysis of the Temperature-Entropy diagram, SAE International, Warrendale, PA, Tech. Rep. 1999-01-1489, May 1999.

[7] MILJIĆ,N.: Investigation of the optimal management of system of the spark engine ignition using artificial neural networks, Doctoral dissertation, Faculty of Mechanical Engineering, University of Belgrade, Belgrade in 2012.

[8] https://fedorabg.bg.ac.rs/fedora/get/o:6236/bdef:Content/get

[9] ZERVAS,E.: Comparative study of some experimental methods to characterize the combustion process in a SI engine, Energy, July 2005, Vol. 30, No. 10, pp. 1803-1816,

[10] BULATOVIĆ,Ž.M.: Identification of the parameters of the equivalent dynamic-torsion system based on the changing flow of the angular speed of the crankshaft, Doctoral dissertation, Faculty of Mechanical Engineering, University of Belgrade, Belgrade February in 2015.

\title{
Praktična istraživanja ugla termodinamičkih gubitaka pri indiciranju pritiska u cilindru dizel motora
}

\begin{abstract}
Vrlo važan literaturni izvor pri proučavanju radnih procesa u cilindrima motora, decenijama unazad, predstavlja članak Güntera Hohenberga "Definition und Eigenschaften des termodinamischen Verlust-winkels von Kolbenmaschinen", objavljen 1976. godine u časopisu Automobil industrie, izdanje 4. Ovim člankom je teoretski i praktično (eksperimentalno) obrađena tema određivanja ugla termodinamičkih gubitaka na krivoj pritiska bez sagorevanja izmerenoj u cilindru motora. Posebna vrednost Hohenbergovih istraživanja je u eksperimentalnim rezultatima dobijenim osrednjavanjem izmerenih podataka na većem broju različitih motora. Pokazalo se da su ti eksperimentalni rezultati i te kako upotrebljivi za brzo, ali dosta tačno, određivanje ugla termodinamičkih gubitaka na krivoj pritiska bez sagorevanja,kod bilo kog motora. Dijagrami koje je predložio Hohenberg su od koristi i danas, bilo da se primenjuju direktno ili služe za poređenje sa rezultatima neke od savremenijih računskih metoda zasnovanih na termodinamičkoj analizi procesa u cilindru motora. Međutim, teoretski prilaz Hohenberga datom problemu kroz jednačine koje je postavio, daje dosta dobru predstavu o najuticajnijim faktorima na veličinu ugla termodinamičkih gubitaka, ali u sebi ima i dosta grešaka i grubih aproksimacija. Dobrim i lošim stranama ovog vrlo važnog literaturnog izvora kroz poređenje sa jednom od savremenih termodinamičkih metoda vezanim za problematiku određivanja ugla termodinamičkih gubitaka, posvećen je ovaj rad.
\end{abstract}

Ključne reči: motor SUS, dizel motor, cilindar motora, stepen kompresije, merenje pritiska, termodinamički gubici. 


\title{
Практическое исследование угла термодинамических потерь при измерении давления в цилиндре дизелей
}

\begin{abstract}
Очень важным литературным источником для изучения рабочих процессов в цилиндрах двигателя, в течение многих десятилетий, статья Гюнтер Хоенберга " Definition und Eigenschaften des termodinamischen Verlust-winkels von Kolbenmaschinen ", опубликованной в 1976 году в журнале Automobil Industrie, издание 4-е. Эта статья является теоретическое и практическое (экспериментальные) сделок с темой определения угла термодинамических потерь на кривой давления без сжигания дозируют в цилиндр двигателя. Особое значение исследований Хоенберга экспериментальных результатов, полученных путем усреднения результатов измерения в нескольких различных двигателя. Было показано, что эти экспериментальные результаты и те, которые являются полезными для быстрого, но довольно точно, определяя угол термодинамических потерь на кривой давления без сжигания, слюбым двигателя. Схемы которие предложил Хоэнберг используются сегодня, будь то применяется непосредственно или использоваться для сравнения с результатами некоторых более современных вычислительных методов, основанных на термодинамической анализа процессов в цилиндре двигателя. Тем не менее, теоретический подход Хоэнберг данная проблема через уравнениях, дает вам довольно хорошее представление о наиболее влиятельных факторов на величины угла термодинамических потерь, но само по себе имеет много ошибок и грубой приближении. Хорошие и плохие стороны это очень важно из литературных источников путем сравнения с одним из современных термодинамических методов, связанных с вопросом определения угла термодинамических потерь, посвящена эта работта.
\end{abstract}

Ключевые слова: двигатель внутреннего сгорания, дизельный двигатель, цилиндр двигателя, степень сжатия, измерение давления, термодинамические потери.

\section{Recherches pratiques de l'angle des pertes thermodynamiques lors de l'indication de la pression dans le cylindre du moteur Diesel}

\begin{abstract}
Une source très importante pour l'étude des processus de travail dans les cylindres de moteur, pendant les décades, représente l'article de Günter Hohenberg «Definition und Eienschaften des termodinalischen Verlust-winkels von Kolbenmaschinen » publié en 1976 dans le magasine "Automobil industrie, édition 4. Cet article traite théoriquement et pratiquement (expérimentalement) le sujet de la détermination de l'angle des pertes thermodynamiques sur la courbe de pression sans combustion mesurée dans le cylindre de moteur. La valeur particulière des recherches de Hohenberg sont les résultats expérimentaux obtenus par la moyenne des données mesurées chez plusieurs moteurs différents. On a constaté que les résultats expérimentaux étaient utilisables pour déterminer vite et assez précisément l'angle des pertes thermodynamiques sur la courbe de pression sans combustion chez n'importe quel moteur. Les diagrammes proposées par Hohenberg s'utilisent encore aujourd'hui appliquée directement ou servant pour la comparaison avec les résultats obtenus par les méthodes modernes numériques basées sur l'analyse thermodynamique du processus dans le cylindre de moteur. Cependant l'approche théorique de Hohenberg au problème posé par les équations qu'il a établies donne une assez bonne idée sur les facteurs les plus influents sur la taille des pertes thermodynamiques mais cette approche contient plusieurs erreurs et des brutes approximations. Ce travail est dédié aux bons et aux mauvais côtés de cette importante source littéraire par la comparaison avec une des méthodes thermodynamiques modernes liées aux problèmes de la détermination de l'angle des pertes thermodynamiques.
\end{abstract}

Mots clés: moteur SUS, moteur Diesel, cylindre de moteur, degré de compression, mesurage de pression, pertes thermodynamiques. 